\title{
Mineralogical and Chemical Model of Belarussian Diatremes
}

\section{V.Bordon}

Institute of Geological Sciences of the Academy of Sciences of Belarus; Minsk, Belarus

In order to reveal new prospection criteria of Kimberlite occurrences in Belarus and proceeding from data available on the geochemical peculiarities of diamodiferous kimberlite fioldes (geo- and petrochemical aspect of diamondiferous province), the author has studied the geochemical and mineralogical specialization of the southern zone, where the Rogachev-Zhlobin kimberlite field discovered in 1989 is located.

A pipe is formed by coarse- medium- and fine-fragmental xenotuff breccias. Rocks are complex heterogenous formations composed of enclosing rock fragments (limestones, dolomites, sandstones, siltstones, quartzites, granitoids, gabbroids, metamorphic rocks), lapilli of volcanic formations (kimberlites, lamproites, picrites) and chlorite-carbonate-serpentine matrix with included xenocrysts (quartz, feldspars, micas, olivine, spinel, etc.).

The main rock-forming minerals of volcanic formations are olivine, phlogopite, clinopyroxene, more seldom melilite, alkali amphibole, pseudoleucite, magnetite, rarely perovskite, sometimes nepheline.

Data obtained were used as the basis to develop a model of Belarussian diatremes involving a series of diagrams -- vertical geochemical section of tuff breccias and their enclosing strata and distribution of trace elements in Devonian deposits laterally overlying a diatreme.

The analysis of this model has recognized indicator elements that are chromium, nickel, scandium, manganese. An anomalous geochemical field shows an insular pattern.

The concentration of the above elements was studied in absorbing rocks of the sedimentary cover, at the basement-cover boundary. The geochemical field shows there a concentric pattern. So, geochemical investigations carried out in the southern zone revealed a complex of efficient geochemical indicators. It appeared to be more scanty than that determined for the Jakutsk diamondiferous province. 